WAHANA

AKUNTANSI

Jumal Ilmiah
Jurnal Ilmiah, Vol 12 (2) 2017, 190-208

WAHANA AKUNTANSI

http://journal.unj.ac.id/unj/index.php/wahana-akuntansi

\title{
PENGARUH KEPEMILIKAN MANAJERIAL DAN KEBIJAKAN DIVIDEN TERHADAP KEBIJAKAN UTANG PADA PERUSAHAAN NON KEUANGAN YANG TERDAFTAR DI BURSA EFEK INDONESIA TAHUN 2015
}

\author{
Diqa Hazna Widya \\ Ati Sumiati* \\ Universitas Negeri Jakarta
}

Keywords:

Managerial Ownership, Dividend Policy, Debt Policy

\begin{abstract}
The purpose of this research was to study the significant effect of Managerial Ownership and Dividend Policy to Debt Policy The NonFinancial sector on Listed Companies in Indonesian Stock Exchange in 2015. The method used is quantitative descriptive survey method with a descriptive and statistical analysis and regression approach. The research using the secondary data obtained from the reference center Indonesia Stock Exchange in 2015. Variable $X$ as the independent variable is Managerial Ownership in measured by Managerial Ownership Ratio (MOWN) and Dividend Policy in measured by Dividend Payout Ratio (DPR). Meanwhile variable $Y$ is proxied by Debt to Equity Ratio (DER). The sampling technique was conducted by random sampling. The attainable population in this research were all manufacture companies listed on the Indonesian Stock Exchange and the sample used by the computation Isaac Michael is 47 companies.The result of this research concluded that Managerial Ownership has not affect the Debt Policy and
\end{abstract}

Abstrak

Tujuan dari penelitian ini adalah untuk mempelajari pengaruh yang signifikan dari Kepemilikan Manajerial dan Kebijakan Dividen terhadap Kebijakan Utang Sektor Non-Keuangan pada Perusahaan Tercatat di Bursa Efek Indonesia pada tahun 2015. Metode yang digunakan adalah metode survei deskriptif kuantitatif dengan analisis deskriptif dan statistik dan pendekatan regresi. Penelitian menggunakan data sekunder yang diperoleh dari pusat referensi Bursa Efek Indonesia tahun 2015. Variabel $\mathrm{X}$ sebagai variabel independen adalah Kepemilikan Manajerial yang diukur dengan Rasio Kepemilikan Manajer (MOWN) dan Kebijakan Dividen yang diukur dengan Dividen Payout Ratio (DPR). Sementara variabel $\mathrm{Y}$ diproksikan dengan Debt to Equity Ratio (DER). Teknik pengambilan sampel dilakukan dengan random sampling. Populasi yang dapat dicapai dalam penelitian ini adalah semua perusahaan manufaktur yang terdaftar di Bursa Efek Indonesia dan sampel yang digunakan oleh komputasi Isaac Michael adalah 47 perusahaan. Hasil penelitian ini menyimpulkan bahwa Kepemilikan Manajerial tidak mempengaruhi Kebijakan Utang dan Kebijakan Dividen dalam memiliki positif. dan berpengaruh signifikan terhadap Kebijakan Utang.

How to Cite:

Widya, Diqa Hazna dan Ati Sumiati. 2017. Pengaruh Kepemilikan Manajerial dan Kebijakan Dividen Terhadap Kebijakan Utang Pada Perusahaan Non Keuangan Yang Terdaftar di Bursa Efek Indonesia Tahun 2015. Jurnal Wahana Akuntansi, 12(2), 86-. https://doi.org/10.21009/wahana.12.026 


\section{PENDAHULUAN}

Dalam suatu perusahaan dibutuhkan keberadaan manajer yang dapat mengambil keputusan yang berdampak penting dalam pengelolaan perusahaan. Keputusan yang diambil bukan sekedar kebijakan perusahaan saja akan tetapi juga kebijakan yang berkaitan dengan keuangan dan finansial perusahaan. Sebelum menentukan kebijakan keuangan manajer juga harus meneliti sifat, biaya dan sumber dana yang akan digunakan karena setiap pendanaan memiliki dampak finansial yang berbeda. Keputusan yang akan di ambil oleh manajer juga harus melindungi kepentingan pemegang saham dan juga harus dapat diterima oleh semua pihak.

Keputusan pendanaan dapat dilakukan dengan berbagai cara yang bisa di dapat dari pendanaan internal atau eksternal seperti menerbitkan saham atau melakukan utang. Keputusan pendanaan dilakukan agar perusahaan mendapatkan dana atau investasi yang dibutuhkan oleh perusahaan dan untuk memenuhi kebutuhan operasional perusahaan.

Untuk memenuhi biaya operasional perusahaan atau untuk melakukan ekspansi perusahaan membutuhkan biaya yang tidak sedikit, oleh karena itu perusahaan cenderung untuk melakukan pendanaan ekternal seperti yang dilakukan oleh PT Provident Agro Tbk yang berhasil meraih pinjaman sebesar Rp719,5 miliar dari PT Bank Rakyat Indonesia Tbk (BBRI) seperti yang dilansir dari harian berita satu berikut: Jakarta - PT Provident Agro Tbk (PALM) berhasil meraih pinjaman sebesar Rp 719,5 miliar dari PT Bank Rakyat Indonesia
Tbk (BBRI). Perseroan mendapatkan pinjaman tersebut melalui dua anak usahanya, yaitu PT Banyan Tumbuh Lestari (BTL) dan PT Inti Global Laksana (IGL) pada 22 Juni 2015. Manajemen Provident Agro menjelaskan bahwa kredit tersebut bakal digunakan untuk ekspansi perseroan di Gorontalo.

Berdasarkan fakta diatas memperkuat dari tujuan pendanaan eksternal perusahan dimana utang dimanfaatkan sebagai modal perusahaan untuk melakukan ekspansi. Selain itu pendanaan dengan utang juga dapat dimanfaatkan oleh beberapa perusahaan untuk membiayai kegiatan operasional perusahaan seperti yang dilakukan oleh PT PP (persero) yang mendapatkan kontrak baru sebesar Rp. 4,98 triliun hingga April 2016 atau sekitar 16,08 persen dari target total kontrak baru tahun ini sebesar RP 31 triliun yang dikutip dari harian okezone berikut: Saat ini, lanjut dia, perseroan sedang mengkaji rencana penggalangan dana melalui dua instrumen, yaitu pinjaman perbankan dan penerbitan surat utang atau obligasi. "Kita akan kombinasikan pinjaman bank dan obligasi dengan memperhatikan suku bunga yang rendah," ungkapnya. Pilihan penerbitan obligasi mempertimbangkan, suku bunga pinjaman perbankan saat ini berkisar 9-9,5 persen, sedangkan untuk obligasi sekitar 8,3 persen. Disebutkan, ruang perseroan untuk mendapatkan dana eksternal masih cukup besar mengingat rasio terhadap utang atau "debt to equity ratio" (DER) perseroan tercatat sebesar 2,7 kali. 
Kebijakan utang harus ditetapkan dengan benar oleh manajer karena akan berdampak buruk untuk suatu perusahaan apabila tidak mempertimbangkan dan mengambil keputusan dengan benar. Manajer juga harus melihat bagaimana keadaan perusahaan untuk mengembalikan kewajiban yang telah dipinjamnya karena suatu perusahaan dapat mengalami kebangkrutan sebagai akibatnya. Sudah banyak perusahaan yang mengalami pailit karena tidak bisa membayarkan utangnya kembali seperti yang di alami oleh PT Wirajaya Packindo yang dilansir dari harian kontan berikut ini JAKARTA. PT Wirajaya Packindo resmi berstatus pailit. Status ini menyusul ditolaknya permohonan perpanjangan penundaan kewajiban pembayaran utang (PKPU) Wirajaya oleh para kreditur.Perusahaan kemasan ini tercatat memiliki total tagihan sebesar Rp 1,27 triliun. Tagihan ini berasal enam kreditur separatis sebesar $\mathrm{Rp} 1,1$ triliun dan 22 kreditur konkuren sebesar Rp 173,34 miliar.

Kebijakan utang dapat ditetapkan oleh manajer keuangan berdasarkan faktor-faktor pertimbangan yang mempengaruhi seperti kepemilikan manajerial, kepemilikan institusional, kebijakan dividen dan profitabilitas dalam suatu perusahaan.

Kepemilikan manajerial adalah dimana manajer memiliki saham perusahaan dengan persentase tertentu. Kepemilikan manajerial dapat mempengaruhi kebijakan utang karena manajer akan lebih berhati-hati dan tidak bersikap oportunis dalam mengambil keputusan mengingat manajer memiliki saham yang apabila kebijakan utang tidak sesuai dengan kondisi perusahaan akan ikut merugikan saham yang dimilikinya. Perusahaan dengan kepemilikan manjerial dan institusional yang tinggi memiliki utang yang lebih kecil seperti perusahaan Aldeyra Therapeutics Inc. (ALDX) yang memiliki kepemilikan insider sebesar $0.74 \%$ dan kepemilikan institusional sebesar $83.52 \%$ memiliki utang sebesar \$1.29 juta dimana keadaan utang perusahaan ini berada pada taraf yang baik sebanding dengan perusahaan disektornya.

Suatu perusahaan yang menyebarkan sahamnya kepada para investor memiliki kebijakan untuk membagikan laba yang didapatkan melalui pembagian dividen yang biasanya dilakukan setahun sekali. Kebijakan dividen yang ditetapkan setiap perusahaan pada umumnya berbeda dilihat dari persentase laba yang akan dibagikan. Semakin besar persentase laba yang akan dibagikan maka akan semakin kecil laba ditahan untuk kebutuhan perusahaan pada tahun yang akan datang sehingga memungkinkan perusahaan tersebut akan berutang untuk memenuhi biaya operasionalnya seperti yang dilakukan oleh PT Adira Dinamika Multi Finance Tbk (Adira Finance) yang dikutip dari harian berita satu berikut ini Jakarta - PT Adira Dinamika Multi Finance Tbk (Adira Finance) memutuskan untuk membagi dividen tunai senilai Rp 332,5 miliar atau setara dengan Rp 332,5 per lembar saham berdasarkan hasil Rapat Umum Pemegang Saham (RUPS), Rabu (18/5). Dividen yang merupakan $50 \%$ laba bersih perusahaan untuk tahun buku 2015 tersebut rencananya akan dibayarkan pada 17 Juni 2016 mendatang. 
Dalam RUPS tersebut, perseoran juga melaporkan penggunaan dana hasil penawaran umum Obligasi Berkelanjutan III Adira Finance. "Setelah biaya penerbitan, dana hasil dari penerbitan obligasi ini digunakan untuk mendanai pembiataan baru," ujar Willy.

Profitabilitas dalam suatu perusahaan juga berpengaruh terhadap kebijakan utang. Apabila laba perusahaan menurun maka perusahaan tersebut akan cenderung menaikan utangnya untuk memenuhi pembiayaan operasional perusahaan seperti yang di alami oleh PT Angkasa Pura II yang dikutip dari harian Okezone Finance berikut iniPT Angkasa Pura II mencatat penurunan tajam dalam laba bersih di semester I-2016. Laba bersih AP II tercatat mengalami penurunan laba bersih Rp574 miliar atau sekira 34,02 persen.Selain itu, AP II juga mencatat kenaikan utang yang cukup signifikan dari Rp4,03 triliun menjadi Rp7,24 triliun. Utang tersebut, berasal dari utang jangka pendek sebesar Rp2 triliun dan utang jangka panjang sebesar Rp5,24 triliun.

Beberapa peneliti telah melakukan penelitian mengenai pengaruh antara kepemilikan manajerial dan kebijakan dividen terhadap kebijakan utang. Berdasarkan penelitian yang dilakukan oleh Andhika (2012) kebijakan dividen dan kepemilikan manajerial berpengaruh signifikan terhadap kebijakan hutang secarastimulan dan kebijakan dividen dan kepemilikan manajerial tidak berpengaruh negatif terhadap kebijakan hutang.

Berdasarkan hasil dari penelitian yang dilakukan oleh Marhamah (2016) kepemilikan manajerial tidak berpengaruh signifikan terhadap kebijakan hutang sedangkan kebijakan dividen berpengaruh positif signifikan terhadap kebijakan hutang.Apit Susanti dan Sekar Mayangsari (2014) juga melakukan penelitian dengan melibatkan variabel kepemilikan manajerial, kebijakan dividen dan kebijakan utang hasil penelitiannya menunjukan bahwa kepemilikan manajerial dan kebijakan dividen tidak berpengaruh terhadap kebijakan utang.

Berdasarkan latar belakang tersebut serta ketidakkonsistenan hasil penelitian terdahulu peneliti tertarik untuk meneliti kembali mengenai "Pengaruh kepemilikan manajerial dan kebijakan dividen Terhadap Kebijakan utang",

\section{KAJIAN TEORETIK \\ Kebijakan Utang}

Utang merupakan kewajiban yang dimiliki perusahaan yang bersumber dari dana ekternal baik yang berasal dari sumber pinjaman perbankan, leasing, penjualan obligasi dan sejenisnya. Sedangkan dari sudut pandang manajemen perusahaan utang dilihat sebagai sumber dana alternatif yang mampu memberikan solusi bersifat konstruktif, baik secara jangka pendek dan jangka Panjang (Fahmi, 2014).

Sedangkan Sawir (2004) menjelaskan bahwa, Pemilihan struktur keuangan, yang menyangkut bauran pendanaan yang berasal dari modal sendiri dan utang yang akan digunakan oleh perusahaan pada akhirnya menyangkut penentuan berapa banyak utang (leverege keuangan) yang akan digunakan oleh perusahaan untuk mendanai aktivanya. Jika perusahaan menggunakan utang, ia memiliki 
kewajiban tetap untuk membayar bunga atas utang yang di ambil dalam rangka pendanaan perusahaan. Sumber pendanaan dapat diperoleh dari modal internal dan modal eksternal, modal internal berasal dari laba ditahan, sedangkan modal eksternal bersumber dari modal sendiri atau melalui utang.

Sedangkan utang menurut Bambang Riyanto adalah modal yang berasal dari luar perusahaan yang sifatnya sementara berada di perusahaan, dan bagi perusahaan yang bersangkutan modal tersebut merupakan hutang yang pada saatnya harus dibayar kembali.

Dari penjelasan diatas dapat disimpulkan bahwa kebijakan utang adalah pendanaan yang bersumber dari dana eksternal didasari atas berapa banyak utang yang akan digunakan untuk menambah dana operasional perusahaan. Terdapat beberapa indikatoryang dapat digunakan dalam pengukuran kebijakan utang. Indikator kebijakan utang yang digunakan dalam penelitian ini yaituDebt to Equity Ratio (DER).Sedangkan Menurut Husnan Rasio ini menunjukan perbandingan antara hutang dengan modal sendiri. Dinyatakan dalam rasio (Husnan, 2000):

\section{Total kewajiban} modal sendiri

\section{Kepemilikan Manajerial}

Kepemilikan manajerial dapat diartikan juga sebagai kepemilikan insider. Menurut Domash (2010) Insiders adalah karyawan kunci dan anggota dewan yang setidaknya memiliki 10 persen dari saham yang beredar. Sedangkan kepemilikan insider adalah persentase dari saham yang beredar yang dimiliki oleh insider.
Menurut Hirschey \& Bentzen (2016) ketika saham dari kepemilikan insider 'besar', sebuah kepentingan diri sendiri dalam kinerja yang sedang berjalan dari perusahaan itu dapat diduga. Manajer dengan kepemilikan yang signifikan memiliki insentif yang jelas untuk menjalankan perusahaan dengan cara memaksimalkan nilai.

Berdasarkan beberapa pengertian diatas dapat disimpulkan bahwa, Kepemilikan manajerial merupakan kondisi dimana manajer perusahaan merangkap jabatan sebagai manajemen perusahaan sekaligus pemegang saham yang turut aktif dalam pengambilan keputusan.

Indikator yang digunakan untuk kepemilikan manajerial dihitung dengan jumlah persentase saham yang dimiliki manajer pada akhir tahun. Pengukuran persentase ini untuk mengetahui besarnya manajerial memiliki saham perusahaan. Secara sistematis kepemilikan manajerial dapat dihitung dengan:

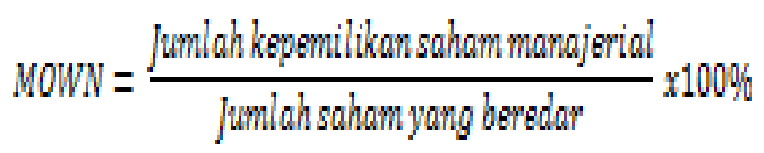

\section{Kebijakan Dividen}

Kebijakan perusahaan membagikan deviden kepada para investor adalah kebijakan yang sangat penting. Kebijakan pembagian deviden (dividend policy) tidak saja membagikan keuntungan yang diperoleh perusahaan kepada para investor tetapi harus selalu diikuti dengan pertimbangan adanya kesempatan investasi kembali (reinvestment). Apabila dividen dibayarkan secara tunai makin meningkat, maka semakin sedikit dana yang 
tersedia untuk reinvestasi. Hal ini menyebabkan tingkat pertumbuhan dimasa mendatang menjadi rendah, sehingga akan menekan harga saham (Rodoni dan Ali, 2010).

Selain itu, Menurut Mardiyanto (2009) Kebijakan dividen adalah seluruh kebijakan manajerial yang dilakukan untuk menetapkan berapa besar laba bersih yang dibagikan kepada para pemegang saham dan berapa besar laba bersih yang tetap ditahan untuk cadangan investasi tahun depan.

Sedangkan menurut Sawir (2004) Kebijakan Dividen menyangkut keputusan apakah laba akan dibayarkan sebagai dividen atau ditahan untuk reinvestasi dalam perusahaan.

Berdasarkan beberapa pengertian diatas dapat disimpulkan bahwa kebijakan dividen adalah kebijakan yang diambil oleh suatu perusahaan untuk menentukan seberapa besar perusahaan tersebut akan membagikan dividen dengan mempertimbangkan cadangan investasi untuk masa yang akan datang.

Indikator yang digunakan adalah Dividen Payout Ratio atau pembayaran dividen (Fahmi, 2014):

\section{Dividen per share \\ Earning per share}

\section{Hasil Penelitian Yang Relevan}

Murtiningtyas (2012) melakukan penelitian dengan judul kebijakan dividen, kepemilikan manajerial, kepemilikan institusional, profabilitas, resiko bisnis terhadap kebijakan hutang. Hasil penelitian adalah Kebijakan deviden, kepemilikan manajerial, kepemilikan institusional, profitabilitas dan resiko bisnis ber-pengaruh signifikan terhadap kebijakan hutang secara simultan. Sedangkan secara parsial hanya profitabilitas dan resiko bisnis yang berpengaruh negatif terhadap kebijakan hutang. Kebijakan de-viden, kepemilikan manajerial, dan kepemilikan institusional tidak berpengaruh negatif terhadap kebijakan hutang.

Marhamah (2016) melakukan penelitian dengan judul Pengaruh kepemilikan manajerial, kepemilikan institusional, kebijakan dividen, pertumbuhan, ukuran perusahaan, dan struktur aktiva terhadap kebijakan hutang perusahaan yang terdaftar di BEI. Hasil dari penelitian ini adalah kepemilikan manajerial tidak berpengaruh signifikan, kepemilikan institusional berpengaruh negatif signifikan, kebijakan deviden berpengaruh positif signifikan, pertumbuhan tidak berpengaruh signifikan, ukuran perusahaan berpengaruh negatif signifikan, struktur aktiva tidak berpengaruh signifikan terhadap kebijakan hutang.

\section{Kerangka Teoritik}

Menurut Masdupi (2005) jika struktur kepemilikan oleh manajemen tinggi, maka manajer akan menjadi risk averse (menghindari risiko). Dalam konteks ini dengan meningkatkan kepemilikan oleh insider, akan menyebabkan insiders semakin berhati-hati dalam menggunakan utang dan menghindari perilaku yang bersifat oportunistik karena mereka ikut menanggung konsekuensinya, sehingga mereka cenderung menggunakan utang yang rendah. Berdasarkan penjelasan 
tersebut diketahui bahwa manajer yang memiliki saham akan menghindari resiko dan berhati-hati dalam menggunakan utang dan cenderung akan menggunakan utang yang rendah.

Kepemilikan saham oleh pihak manajemen akan menimbulkan suatu pengawasan terhadap kebijakan yang diambil oleh manajemen perusahaaan. Termasuk kebijakan untuk memakai hutang. Pihak pemegang saham cenderung berkeinginan untuk mengurangi penggunaan hutang karena dengan banyaknya hutang akan meningkatkan risiko perusahaan (Marhamah, 2016). Sehingga manajer yang memiliki saham akan cenderung mengurangi utang perusahaan untuk menghindari risiko yang akan dialami perusahaan.

Menurut Sudana (2011) agar pihak manajemen bertindak sejalan dengan kepentingan pemilik perusahaan, dapat dilakukan upaya sebagaimana dikemukakan oleh Jensen dan Meckling, bahwa pemilik dapat menjamin pihak manajemen akan membuat keputusan yang optimal hanya jika diberikan insentif yang cukup memadai dan manajemen merupakan pihak yang minoritas. Insentif bisa berupa, opsi saham, bonus, mobil dan kantor yang mewah, yang besarnya sangat tergantung pada seberapa dekat keputusan yang diambil oleh pihak manajemen dengan kepentingan pemilik. Dilihat dari penjelasan tersebut upaya yang dilakukan untuk menyesuaikan kepentingan pemilik perusahaan dan manajer adalah dengan memberikan insentif yang bisa berupa saham dan akan membuat manajer membuat keputusan yang optimal yang bisa menyangkut kebijakan utang perusahaan.
Berdasarkan pendapat dari beberapa teori diatas maka dapat disimpulkan bahwa kepemilikan manajerial mempunyai peranan dalam mengendalikan keputusan kebijakan utang yang akan di ambil oleh pihak manajer dan akan cenderung lebih berhati-hati dalam menggunakan pendanaan yang berasal dari utang.

Menurut Husnan (2000) apabila perusahaan cenderung membagikan dividen yang besarnya tetap, maka pembayaran dividen tersebut akan merupakan beban tetap bagi perusahaan. Dengan demikian maka perusahaan yang menggunakan leverage yang tinggi akan sulit untuk mempertahankan pembayaran dividen yang tetap tersebut. Hal ini disebabkan karena leverage yang tinggi juga akan menimbulkan beban tetap yang tinggi pula. Sehingga perusahaan yang membagikan dividen yang besar dan tetap akan menyulitkan bagi perusahaan yang memiliki utang yang besar karena akan menimbulkan beban yang tinggi.

Menurut Sudana (2011) salah satu sumber dana perusahaan adalah berasal dari pinjaman. Perusahaan dimungkinkan untuk membayar dividen yang besar, karena perusahaan masih memiliki peluang atau kemampuan untuk memperoleh dana dari pinjaman guna memenuhi kebutuhan dana yang diperlukan perusahaan. Hal ini dimungkinkan karena laverage keuangan perusahaan masih rendah, dan perusahaan dipercaya oleh para kreditor. Dengan demikian, semakin besar kemampuan perusahaan untuk meminjam semakin besar dividen yang dibayarkan kepada pemegang saham. Berdasarkan penjelasan ini apabila 
perusahaan membagikan dividen dengan rasio yang besar akan memungkinkan untuk perusahaan tersebut akan meminjam utang sebagai modal untuk memenuhi dana perusahaan.

Menurut Nuringsih (2011) kebijakan dividen juga mempengaruhi kebijakan utang, hal ini disebabkan penggunaan dividen pada tingkat tinggi menyebabkan presentase laba ditahan menjadi rendah, sehingga jika perusahaan membutuhkan tambahan dana akan menggunakan sumber dana eksternal. Dilihat dari penjelasan ini apabila perusahaan membagikan dividen dengan nilai yang tinggi akan menyebabkan laba ditahan menjadi berkurang dan perusahaan akan membutuhkan tambahan dana dengan cara berutang.

Berdasarkan pendapat dari beberapa teori diatas maka dapat disimpulkan bahwa kebijakan dividen yang akan di bagikan oleh perusahaan akan berpengaruh terhadap kebijakan utang yang akan di ambil oleh suatu perusahaan.

Agency cost dapat dikurangi dengan: pertama dengan meningkatkan kepemilikan saham perusahaan oleh manajemen. Kedua dengan meningkatkan dividend payout ratio sehingga tidak tersedia banyak free cash flow dan manajemen terpaksa mencari pendanaan dari luar untuk membiayai investasinya (Murtiningtyas, 2011). Berdasarkan penjelasan ini terlihat bahwa biaya keagenan dapat dikurangi dengan kepemilikan saham dan peningkatan pembayaran dividen yang menuntun manajemen untuk berutang.

Menurut Bringham dan Houston (2011) konflik kepentingan bisa saja terjadi jika manajer dan pemegang saham memiliki tujuan yang berbeda. Konflik seperti ini akan terjadi ketika perusahaan memiliki lebih banyak kas dari yang dibutuhkan untuk mendukung operasi utama perusahaan. Sedangkan apabila manajer dengan arus kas yang terbatas akan memiliki kemampuan yang lebih kecil untuk melakukan pengeluaran sia-sia. Perusahaan dapat mengurangi kelebihan arus kas dengan berbagai macam cara salah satunya adalah mengalirkan sebagian diantaranya kembali ke pemegang saham melaui dividen yang lebih tinggi atau pembelian saham kembali dan pelayanan utang yang lebih tinggi sehingga menuntut manajer untuk lebih disiplin. Sehingga untuk membuat manajer tidak melakukan pengeluaran yang siasia dan mengefektifkan utang, perusahaan harus mengurangi arus kas dengan cara pembagian dividen dan memberikan saham kepada manajer untuk mengurangi konflik kepetingan.

Rozeff (2005) menyatakan bahwa pembayaran dividen adalah bagian dari monitoring aktivitas perusahaan oleh principal terhadap pihak manajemen sebagai agent. Dalam kondisi demikian perusahaan akan cenderung untuk membayar dividen yang lebih besar jika manajer memiliki proporsi saham yang lebih rendah. karena semakin tinggi dividen yang dibayarkan kepada pemegang saham maka free cash flow dalam perusahaan semakin kecil sehingga manajer harus memikirkan untuk memperoleh sumber dana dari luar yang bisa saja berupa hutang. Dengan demikian akan mengurangi kekuasaan manajer terhadap pengendalian terhadap perusahaan, karena dengan adanya entitas lain yang memberikan hutang kepada pihak perusahaan 
maka entitas tersebut juga berkepentingan untuk melakukan pengawasan terhadap jalannya perusahaan

Berdasarkan penjelasan diatas terlihat bahwa pembayaran dividen dapat menjadi pengawasan terhadap kinerja manajer untuk mengambil keputusan dalam melakukan kebijakan utang dan cenderung akan membayarkan dividen yang tinggi apabila kepemilikan saham oleh manajer rendah.

Berdasarkan pendapat dari beberapa teori diatas maka dapat disimpulkan bahwa kebijakan dividen dan kepemilikan manajerial akan berpengaruh terhadap kebijakan utang yang akan di ambil oleh suatu perusahaan.

\section{Perumusan Hipotesis}

Berdasarkan permasalahan yang ada dan teori yang ada, maka dapat dirumuskan hipotesis penelitian sebagai berikut:

1. Terdapat pengaruh antara kepemilikan manajerial dan kebijakan utang.

2. Terdapat pengaruh antara kebijakan dividen dan kebijakan utang.

3. Terdapat pengaruh antara kepemilikan manajerial, kebijakan dividen dan kebijakan utang.

\section{METODOLOGI PENELITIAN}

Objek penelitian ini adalah perusahaan non keuangan yang terdaftar di Bursa Efek Indonesia pada tahun 2015. Jenis data yang digunakan dalam penelitian ini adalah data kuantatif berupa laporan keuangan perusahaan non keuangan di BEI tahun 2015. Sumber datanya merupakan data sekunder yang meliputi data-data di BEI tahun 2015.
Metode penelitian ini menggunakan metode kuantitatif guna mengetahui seberapa besar pengaruh antara kepemilikan manajerial (sebagai variabel $\mathrm{X}_{1}$ ) dan kebijakan dividen (sebagai variabel $\mathrm{X}_{2}$ ) terhadap kebijakan utang (sebagai variabel Y).

Populasi dalam penelitian ini adalah seluruh perusahaan non keuanganyang terdaftar di Bursa Efek Indonesia pada tahun 2015 berjumlah 423 perusahaan. Populasi terjangkau dari penelitian ini diambil menggunakan suatu kriteria. Kriteria yang digunakan pada penelitian ini, yaitu terdapat pada Tabel 1 di bawah ini.

\section{Tabel 1}

\section{Kriteria Pemilihan Sampel}

\begin{tabular}{|l|c|}
\hline \multicolumn{1}{|c|}{ Kriteria } & Jumlah Perusahaan \\
\hline $\begin{array}{l}\text { Perusahaan non keuangan yang Tercatat di Bursa } \\
\text { Efek Indonesia (BEI) Tahun 2015 }\end{array}$ & 423 \\
\hline $\begin{array}{l}\text { Perusahaan non keuangan yang tidak memiliki saham } \\
\text { manajerial pada tahun 2015 }\end{array}$ & $(291)$ \\
\hline $\begin{array}{l}\text { Perusahaan non keuangan yang tidak membagikan } \\
\text { dividen pada tahun 2015 }\end{array}$ & $(79)$ \\
\hline $\begin{array}{l}\text { Jumlah Perusahaan non keuangan yang } \\
\text { Memenuhi Kriteria }\end{array}$ & $\mathbf{5 3}$ \\
\hline
\end{tabular}

Sumber: Data Diolah Penulis, Tahun 2017

Jumlah sampel ditentukan secara acak sederhana (simple random sampling). Penentuan jumlah sampel menggunakan tabel yang dikembangkan oleh Issac dan Michael, dengan mengambil taraf kesalahan 5\%. Berdasarkan tabel Issac dan Michael, maka peneliti mendapatkan 47 perusahaan yang dapat diambil secara acak sebagai sample penelitian. 
Pengujian hipotesis yang dilakukan dalam penelitian ini menggunakan regresi linier berganda. Analisis ini digunakan untuk menguji pengaruh dua atau lebih variabel independen terhadap variabel dependen menggunakan model regresi linier berganda. Berdasarkan pengembangan hipotesis di atas maka dapat diterapkan model regresi berganda. Dalam regresi linier berganda, diperlukan uji asumsi klasik yaitu uji normalitas, uji multikolinearitas, uji heteroskedastisitas, uji autokorelasi dan pengujian hipotesis simultan (uji F) serta uji parsial (uji T).

\section{HASIL DAN PEMBAHASAN}

\section{Uji Normalitas}

Uji normalitas digunakan untuk mengetahui apakah sampel yang berasal dari populasi data berdistribusi normal atau tidak. Jika data tidak berdistribusi normal maka kesimpulan statistik menjadi tidak valid atau bias. Dalam penelitian ini, uji normalitas dilakukan dengan Normal Probably Plot (P-P Plot) dan Uji One Sample Kolmogrov-Smirnov Test. Hasil uji normalitas penelitian ini terdapat pada Gambar 1 dan Tabel 2.

Dari Gambar 1 dapat dilihat bahwa titiktitik menyebar di sekitar garis diagonal dan mengikuti arah garis diagonal. Hal tersebut menunjukkan bahwa variabel yang digunakan dalam penelitian ini memenuhi asumsi normalitas.

Berdasarkan Tabel 2, dapat dilihat bahwa semua variabel di dapat signifikan sebesar 0,193. Nilai signifikansi di atas 0,05 mengindikasikan bahwa nilai residual memiliki distribusi yang normal.

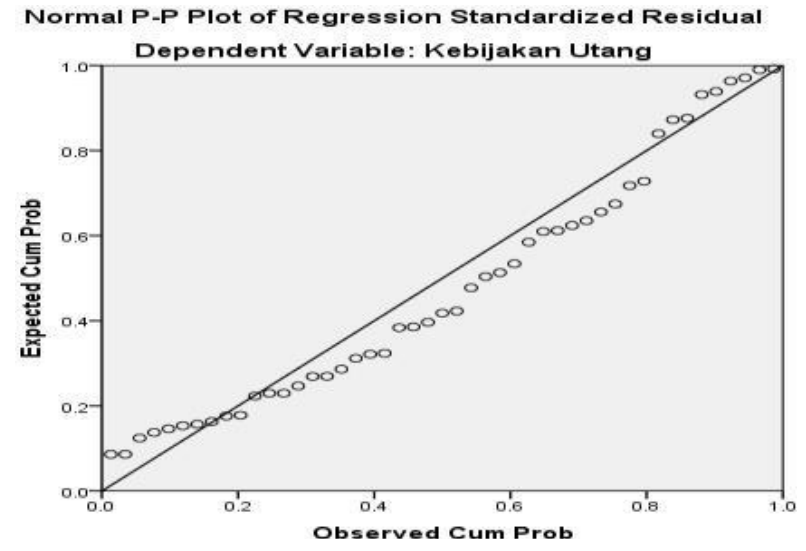

Gambar 1

Hasil Uji Normalitas

Sumber: Data Diolah Penulis, Tahun 2017

\section{Uji Multikolinearitas}

Uji multikolinieritas digunakan untuk mengetahui apakah pada model regresi ditemukan adanya korelasi antar variabel independen. Model uji regresi yang baik selayaknya tidak terjadi multikolinieritas. Kriteria suatu model regresi yang bebas multikoliniearitas adalah mempunyai nilai VIF (Variance Inflation Factor) $<10$ dan mempunyai nilai tolerance $>0,10$, Hasil uji multikolinearitas peneitian ini terdapat pada Tabel 3 di bawah.

Tabel 3

\section{Hasil Uji Multikolineari}

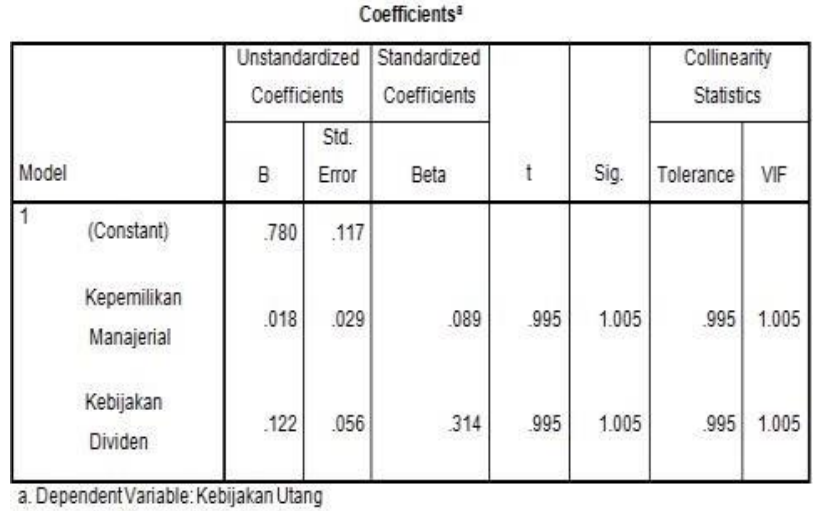

Sumber: Data Diolah Penulis, Tahun 2017 
Berdasarkan tabel diatas, dapat dilihat bahwa nilai tolerance untuk variabel kepemilikan manajerial dan kebijakan dividen adalah 0,995>0,1 (tolerance $>0,1$ ) dan nilai VIF untuk variabel kepemilikan manajerial dan kebijakan dividen adalah $1,005<10$ (VIF $<10)$. Jadi, dapat disimpulkan semua variabel memiliki nilai tolerance $>0,1$ dan nilai VIF < 10 yang berarti tidak terdapat persoalan multikolinieritas antara variabel independen.

\section{Uji Heteroskedastisitas}

Uji heteroskedastisitas digunakan untuk mengetahui adanya ketidaksamaan varian dari residual untuk semua pengamatan pada model regresi. Uji heteroskedastisitas dapat dilakukan dengan mengamati gambar scatter plot di bawah ini.

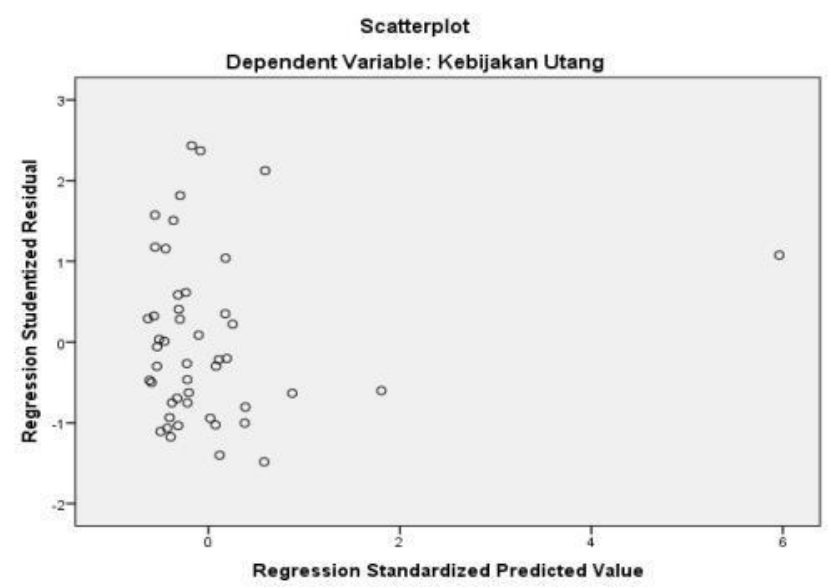

Gambar 2

\section{Hasil Uji Heteroskedasitas}

Sumber: Data Diolah Penulis, Tahun 2017

Berdasarkan gambar tersebut dapat dilihat bahwa scatter plot tidak memperlihatkan sebuah pola tertentu yang teratur seperti bergelombang, melebar, kemudian menyempit dan scatter plot juga memperlihatkan titik-titik menyebar di atas dan di bawah angka 0 pada sumbu Y. Hal ini berarti menunjukkan bahwa model regresi dalam penelitian ini bebas dari persoalan heteroskedastisitas.

Uji heteroskedastisitas juga dapat dilakukan dengan pengujian Spearman's Rho. Metode uji heteroskedastisitas dengan korelasi Spearman's Rho yaitu mengkorelasikan variabel independen dengan nilai unstrandardized residual. Jika korelasi antar variabel dengan nilai residual mendapat signifikansi lebih dari 0,05 $(>0,05)$, maka tidak terjadi masalah heteroskedastisitas. Hasil pengujian Spearman's Rho penelitian ini terdapat pada Tabel 4 di bawah.

\section{Tabel 4}

\section{Hasil Uji Spearman's Rho}

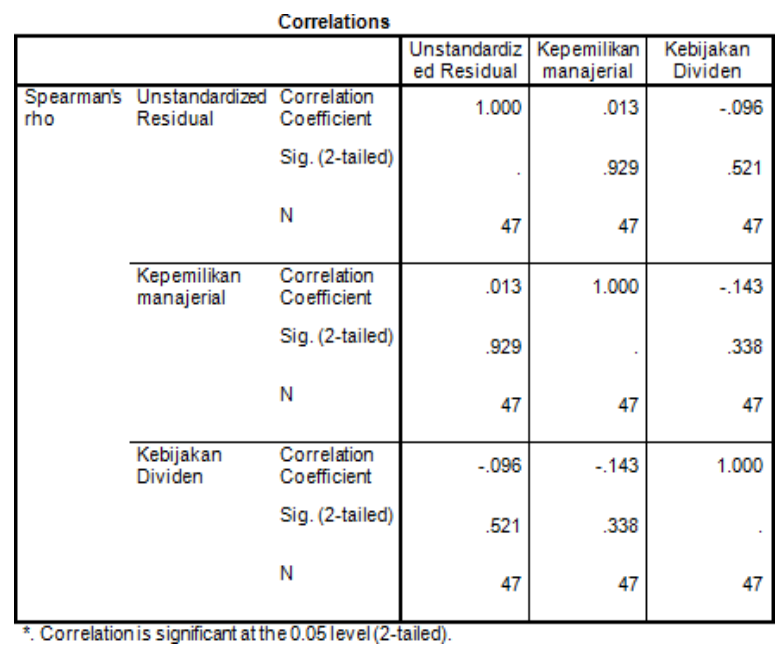

Sumber: Data Diolah Penulis, Tahun 2017

Berdasarkan hasil pengujian pada tabel di atas, dapat dilihat bahwa korelasi antar variabel independen dengan nilai residual mendapatkan nilai signifikansi lebih dari 0,05. Jadi, dapat diberi kesimpulan bahwa varian residual model regresi pada penelitian ini homogen atau model regresi terbebas dari persoalan heteroskedastisitas. 


\section{Uji Autokorelasi}

Uji autokorelasi digunakan untuk mengetahui ada atau tidaknya penyimpangan asumsi klasik autokorelasi, yaitu korelasi yang terjadi antara residual pada satu pengamatan dengan pengamatan lain pada modal regresi. Model regresi yang baik adalah yang tidak terjadi autokorelasi. Untuk mendeteksi ada atau tidaknya autokorelasi dapat dilakukan dengan pengujian Durbin-Watson (DW). Hasil uji autokorelasi dari penelitian ini terdapat pada Tabel 5 di bawah ini.

Tabel 5

Hasil Uji Autokorelasi

\begin{tabular}{|c|c|c|c|c|c|}
\hline \multicolumn{6}{|c|}{ Model Summaryb } \\
\hline Model & $\mathrm{R}$ & $\begin{array}{l}\mathrm{R} \\
\text { Squa } \\
\text { re }\end{array}$ & $\begin{array}{l}\text { Adjuste } \\
\text { d R } \\
\text { Square }\end{array}$ & $\begin{array}{l}\text { Std. Error } \\
\text { of the } \\
\text { Estimate }\end{array}$ & $\begin{array}{l}\text { Durbin- } \\
\text { Watson }\end{array}$ \\
\hline 1 & $.320^{\mathrm{a}}$ & .103 & .062 & .5846878 & 1.690 \\
\hline \multicolumn{6}{|c|}{$\begin{array}{l}\text { a. Predictors: (Constant), Kebijakan Dividen, } \\
\text { Kepemilikan manajerial }\end{array}$} \\
\hline \multicolumn{6}{|c|}{ b. Dependent Variable: Kebijakan utang } \\
\hline
\end{tabular}

Sumber: Data Diolah Penulis, Tahun 2017

Berdasarkan tabel diatas, dapat dilihat bahwa angka Durbin-Watson (DW) hitung adalah 1,690. Untuk taraf signifikansi sebesar $5 \%$ dengan jumlah sampel $47(n=47)$ dan 2 variabel independen $(\mathrm{k}=2)$, maka berdasarkan tabel Durbin-Watson (DW) diperoleh $\mathrm{dL}=$ 1,4435, dan dU=1,6204 sedangkan nilai (4-dU) $=2,3769$, maka dapat disimpulkan bahwa data dalam model regresi terbebas dari permasalahan autokorelasi.

\section{Persamaan Regresi Linier Ganda}

Pada penelitian ini, pengujian dilakukan dengan analisis regresi linear berganda, yaitu suatu metode statistik yang umum digunakan untuk menelitihubungan antara sebuah variabel dependen dengan beberapa variabel independen, apakah masing-masing variabel independen berhubungan positif atau negatif dan untuk memprediksi nilai dari variabel dependen apabila terjadi kenaikan atau penurunan pada variabel independen. Hasil analisis regresi linier berganda pada penelitian ini terdapat pada Tabel 6 di bawah ini.

Tabel 6

\section{Hasil Analisis Regresi Linier Berganda}

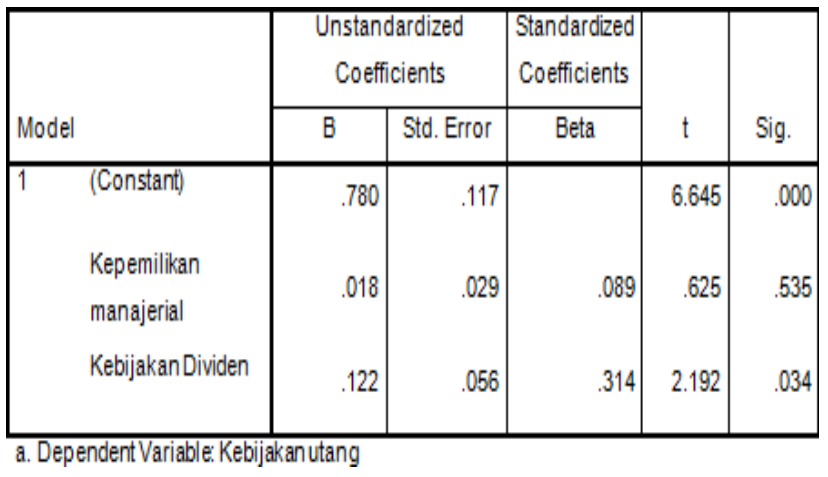

Sumber: Data Diolah Penulis, Tahun 2017

Berdasarkan hasil analisis regresi. maka diperoleh persamaa regresi sebagai berikut:

$$
\hat{\mathrm{Y}}=0,780+0,018 \mathrm{X}_{1}+0,122 \mathrm{X}_{2}
$$

Dari hasil tersebut dapat dijelaskan, sebagai berikut :

1. Konstanta (a) sebesar 0,780. Hal ini berarti jika nilai dari kepemilikan manajerial dan kebijakan dividen pada objek penelitian tidak mengalami kenaikan dan penurunan atau sama dengan nol (0), maka kebijakan utang bernilai 0,780 .

2 Koefisien $b_{1}=0,018$. Hal ini berarti jika kenaikan nilai kepemilikan manajerial sebesar 1, sementara variabel independen lain bersifat tetap maka menyebabkan 
variabel $\mathrm{Y}$ akan meningkat 0,018 . Koefisien bernilai positif menunjukkan terjadinya hubungan positif antara kepemilikan manajerial dengan kebijakan utang.

3. Koefisien $\mathrm{b}_{2}$ sebesar 0,122 . Hal ini berarti jika nilai kebijakan dividen mengalami kenaikan sebesar 1, sementara variabel independen lain bersifat tetap maka menyebabkan variabel Y akan mengalami kenaikan sebesar 0,122. Koefisien bernilai positif menunjukkan terjadinya hubungan positif antara kebijakan dividen dengan kebijakan utang.

\section{Uji Regresi Simultan (Uji F)}

Uji simultan (Uji F) bertujuan untuk mengukur apakah semua variabel independen yang dimasukkan dalam model mempunyai pengaruh secara bersama-sama terhadap variabel dependen. Hasil Uji F dari penelitian ini terdapat pada Tabel 7 di bawah ini.

\section{Tabel 7}

\section{Hasil Uji F}

ANOVA:

\begin{tabular}{|c|c|c|c|c|c|}
\hline Model & Sum of Squares & Df & Mean Square & $F$ & Sig. \\
\hline $1 \quad$ Regression & 1.720 & 2 & .860 & 2.516 & $.092^{\circ}$ \\
\hline Residual & 15.042 & 44 & .342 & & \\
\hline Total & 16.762 & 46 & & & \\
\hline
\end{tabular}

a. Dependent Variable: Kebjiakanutang

b. Predictors: (Constant), Kebjijakan Dividen, Kepemilikanmanajerial

Sumber: Data Diolah Penulis, Tahun 2017

Hasil uji ANOVA antara kepemilikan manajerial dan kebijakan dividen terhadap kebijakan utang menunjukkan bahwa nilai $\mathrm{F}_{\text {hitung }}=2,516$, sedangkan $\mathrm{F}_{\text {tabel }}$ dengan $\mathrm{df}_{1}=2$ dan $\mathrm{df}_{2}=44$ yaitu sebesar 3,200 . Hal ini berarti nilai $F_{\text {hitung }}<F_{\text {tabel }}(2,516<3,200)$ sehingga dapat disimpulkan tidak terdapat pengaruh antara variabel kepemilikan manajerial dankebijakan dividen secara bersama-sama terhadap kebijakan utang. Nilai signifikansi yaitu 0,092 > 0,05, sehingga menunjukkan tidak ada pengaruh yang signifikan. Jadi, dapat disimpulkan bahwa kepemilikan manajerial dan kebijakan dividen tidak berpengaruh terhadap kebijakan utang.

\section{Uji Regresi Parsial (Uji t)}

Uji regresi parsial dilakukan untuk mengetahui apakah masing-masing variabel independen (X) dalam model regresi mempunyai pengaruh yang nyata atau signifikan terhadap variabel dependen (Y). Hasil Uji $\mathrm{t}$ dari penelitian ini terdapat pada Tabel 8 di bawah ini.

\section{Tabel 8}

\section{Hasil Uji t}

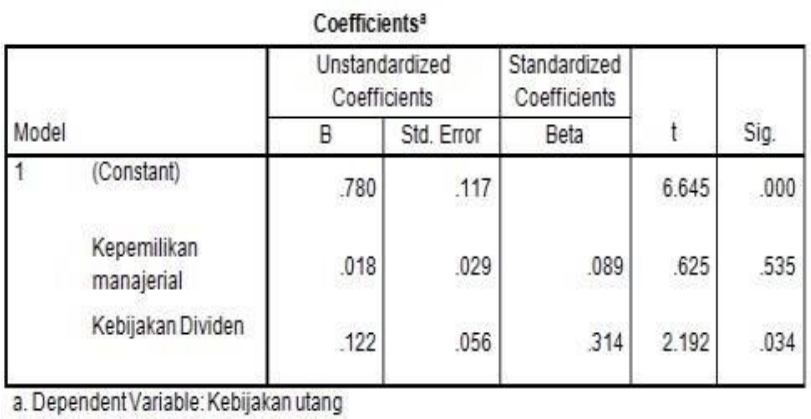

Sumber: Data Diolah Penulis, Tahun 2017

Hasil pengujian hipotesis secara parsial (uji t):

1. Berdasarkan tabel di atas, nilai $\mathrm{t}$ hitung kepemilikan manajerial adalah 0,625, maka $t_{\text {hitung }}<\mathrm{t}_{\text {tabel }}$ yaitu $0,625<2,000$, 
hasil ini menunjukkan bahwa $\mathrm{H}_{0}$ diterima.

Nilai signifikansi dalam tabel adalah 0,535 lebih besar dari tingkat signifikansi yaitu $\quad 0,05 \quad(0,535<0,05), \quad$ sehingga menunjukkan pengaruh yang tidak signifikan. Secara parsial dapat disimpulkan bahwa tidak terdapat pengaruh antara kepemilikan manajerial dengan kebijakan utang, sehingga hipotesis pertama dalam penelitian ini tidak diterima.

2. Berdasarkan tabel di atas, nilai t hitung kebijakan dividen adalah 2,192, maka $t_{\text {hitung }}>t_{\text {tabel }}$ yaitu $2,192>2,000$, hal itu menunjukkan bahwa $\mathrm{H}_{0}$ ditolak. Nilai signifikansi dalam tabel adalah 0,034 lebih kecil dari tingkat signifikansi yaitu $0,05(0,034<0,05)$, sehingga menunjukkan pengaruh yang signifikan. Secara parsial dapat disimpulkan bahwa terdapat pengaruh positif dan signifikan antara kebijakan dividen dengan kebijakan utang, sehingga hipotesis kedua dalam penelitian ini dapat diterima.

\section{Uji Koefisien Korelasi Ganda}

Uji koefisien korelasi ganda digunakan untuk mengetahui seberapa besar hubungan antara dua atau lebih variabel independen terhadap variabel dependen secara serentak. Hasil uji koefisien korelasi ganda dari penelitian ini terdapat pada Tabel 9 di bawah.

Berdasarkan Tabel 9, diketahui nilai korelasi ganda yang disimbolkan dengan $\mathrm{R}$ adalah sebesar 0,320. Hal ini menunjukkan adanya hubugan yang rendah antara variabel kepemilikan manajerial dan kebijakan dividen terhadap kebijakan utang.

Tabel 9

Hasill Uji Koefisien Korelasi Ganda

Model Summary ${ }^{0}$

\begin{tabular}{|r|r|r|r|r|}
\hline Model & \multicolumn{1}{|c|}{$R$} & R Square & \multicolumn{1}{c|}{$\begin{array}{c}\text { Adjusted R } \\
\text { Square }\end{array}$} & $\begin{array}{c}\text { Std. Error of the } \\
\text { Estimate }\end{array}$ \\
\hline & $.320^{\mathrm{3}}$ & .103 & .062 & .58469 \\
\hline
\end{tabular}

b. DependentVariable: Kebijakan utang

Sumber: Data Diolah Penulis, Tahun 2017

\section{Koefisien Determinasi}

Uji koefisien determinasi digunakan untuk mengetahui seberapa besar persentase dari tingkat keterikatan antara varaibel dependen dengan variabel indenpenden. Hasil uji koefisien determinasi dari penelitian ini terdapat pada Tabel 10 di bawah.

\section{Tabel 10}

\section{Hasill Uji Koefisien Determinasi}

Model Summary ${ }^{0}$

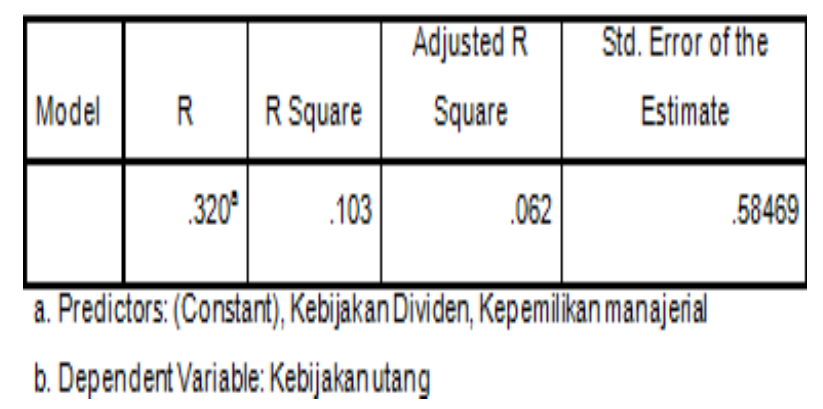

Sumber: Data Diolah Penulis, Tahun 2017

Berdasarkan tabel di atas, dapat diketahui bahwa nilai $\mathrm{R}$ Square $\left(\mathrm{R}^{2}\right)$ sebesar 0,103 . Hal ini menunjukkan bahwa pengaruh kepemilikan manajerial dan kebijakan dividen terhadap kebijakan utang sebesar 0,103 atau 10,30\%. 
Jadi dapat disimpulkan bahwa variabel independen (kepemilikan manajerial dan kebijakan dividen) mampu menjelaskan sebesar $10,30 \%$ variabel dependen (kebijakan utang).

\section{PEMBAHASAN}

Berdasarkan hasil uji statistik, diperoleh tidak adanya pengaruh antara kepemilikan manajerial terhadap kebijakan utang. Hal ini dapat dilihat berdasarkan nilai thitung dengan $t_{\text {tabel }}$ yaitu 0,625> 2,000, dan nilai signifikan menunjukkan pengaruh yang tidak signifikan yaitu $0,535<0,05$. Tanda positif pada nilai $t_{\text {hitung }}$ menandakan tidak adanya pengaruh positif diantara kepemilikan manajerial terhadap kebijakan utang artinya jika kepemilikan manajerial meningkat kebijakan utang tidak meningkat. Begitu pula sebaliknya, jika kepemilikan manajerial menurun maka kebijakan utang tidak menurun.

Hasil penelitian ini mendukung pendapat Masdupi (2005) jika struktur kepemilikan oleh manajemen tinggi, maka manajer akan menjadi risk averse (menghindari risiko). Dalam konteks ini dengan meningkatkan kepemilikan oleh insider, akan menyebabkan insiders semakin berhati-hati dalam menggunakan utang dan menghindari perilaku yang bersifat oportunistik karena mereka ikut menanggung konsekuensinya, sehingga mereka cenderung menggunakan utang yang rendah. Sedangkan berdasarkan hasil penelitian ini terlihat tidak adanya pengaruh antara kepemilikan manajerial dan kebijakan utang dikarenakan masih rendahnya persentase kepemilikan manajerial sehingga manajer tidak menjadi penghindar resiko dalam mengambil kebijakan utang.
Hasil penelitian ini juga sejalan dengan penelitian sebelumnya yang dilakukan oleh Murtiningtyas (2012), dimana memperoleh $t_{\text {hitung }}$ sebesar 0,318 dan nilai signifikansi sebesar 0,753. Berdasarkan hasil peroleh tersebut disimpulkan bahwa variabel kepemilikan manajerial tidak berpengaruh positif dan signifikan terhadap kebijakan utang. Selain itu, hasil penelitian ini juga sejalan penelitian sebelumnya yang dilakukan oleh Marhamah (2016) dimana memperoleh

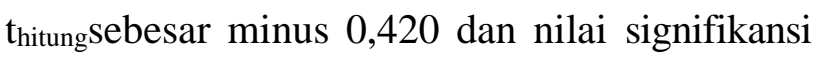
sebesar 0,676 hal ini menunjukan bahwa variabel kepemilikan manajerial tidak berpengaruh signifikan terhadap kebijakan hutang.

Berdasarkan hasil uji statistik, diperoleh adanya pengaruh positif dan signifikan antara kebijakan dividen terhadap kebijakan utang. Hal ini dapat dilihat berdasarkan nilai thitung dengan $t_{\text {tabel }}$ yaitu $2,192<2,000$ dan nilai signifikan $0,034<0,05$. Hal ini menunjukkan bahwa apabila kebijakan dividen meningkat maka kebijakan utang juga akan meningkat.Begitu pula sebaliknya, jika kebijakan dividen menurun maka kebijakan utang juga akan menurun.

Hasil penelitian ini mendukung pandangan mengenai kebijakan dividen yaitu apabila perusahaan cenderung membagikan dividen yang besarnya tetap, maka pembayaran dividen tersebut akan merupakan beban tetap bagi perusahaan. Dengan demikian maka perusahaan yang menggunakan leverage yang tinggi akan sulit untuk mempertahankan pembayaran dividen yang tetap tersebut. Hal ini 
Hal ini disebabkan karena leverage yang tinggi juga akan menimbulkan beban tetap yang tinggi pula (Husmam, 2000).

Berdasarkan hasil penelitian ini terlihat bahwa adanya pengaruh positif dan signifikan antara kebijakan dividen dengan kebijakan utang, hal ini terlihat dari besarnya rasio pembagian dividen yang sejalan dengan besarnya rasio utang dalam perusahaan sehingga apabila suatu perusahaan memutuskan untuk membagikan dividen dengan rasio yang besar maka perusahaan tersebut akan menaikan rasio utang untuk menambah biaya operasional pada periode berjalan.

Hasil penelitian ini sejalan dengan penelitian sebelumnya yang dilakukan oleh Marhamah (2016) yang menguji hipotesis ketiganya yaitu pengaruh kebijakan dividen terhadap kebijakan utang dengan hasil pengujian koefisien parameter sebesar 0 , $t_{\text {hitung }}$ sebesar 2,037 dan tingkat signifikansi sebesar 0,047 yang berarti variabel kebijakan dividen berpengaruh positif dan signifikan terhadap kebijakan utang.

Berdasarkan hasil uji regresi secara simultan menujukkan bahwa kepemilikan manajerial dan kebijakan dividen secara bersama-sama tidak berpengaruh positif dan signifikan terhadap kebijakan utang. Hal ini dapat dilihat berdasarkan nilai $F_{\text {hitung dengan }}$ $F_{\text {tabel }}$ yaitu 2,516> 3,200 dan bernilai positif. Nilai signifikan menunjukkan pengaruh yang tidak signifikan yaitu $0,092<0,05$.

Dengan demikian, hasil ini tidak sesuai dengan $\mathrm{H}_{3}$ yang dibuat sehingga $\mathrm{H}_{3}$ ditolak. Untuk besarnya pengaruh kedua variabel independen tersebut terhadap variabel dependen, dilihat dari koefisien determinasinya yaitu sebasar 0,103 yang dapat disimpulkan terjadi hubungan serentak antara variabel terikat dan variabel bebas sebesar 10,30\%. Kebijakan utang dalam penelitian ini dipengaruhi oleh kepemilikan manajerial dan kebijakan dividen sebesar $10,30 \%$.

Penelitian ini memiliki keterbatasan, yaitu: penelitian ini terbatas pada sampel perusahaan non-keuangan dalam satu tahun saja dan terbatas pada informasi yang dibutuhkan untuk penelitian yang menyebabkan sampel penelitian pada perusahaan non-keuangan yang menjadi sedikit. Selain itu, penelitian ini hanya meneliti dua variabel saja yang mempengaruhi kebijakan utang yaitu kepemilikan manajerial dan kebijakan dividen sedangkan masih banyak variabel lain yang juga memiliki pengaruh terhadap kebijakan utang.

\section{Kesimpulan}

Penelitian ini bertujuan untuk mengetahui pengaruh kepemilikan manajerial dan kebijakan dividen terhadap kebijakan utang. Berdasarkan analisis hasil pengujian data dan pembahasan yang telah dilakukan, maka dapat diambil suatu kesimpulan sebagai berikut :

1. Kebijakan manajerial tidak memiliki pengaruh positif dan signifikan terhadap kebijakan utang. Hal ini berarti jika kepemilikan manajerial tinggi, maka kebijakan utang tersebut belum tentu akan tinggi. Begitu pula, jika kepemilikan manajerial rendah, maka kebijakan utang tersebut belum tentu akan rendah. 
2 Kebijakan dividen memiliki pengaruh positif dan signifikan terhadap kebijakan utang. Hal ini berarti jika kebijakan dividen tinggi, maka kebijakan utang tersebut akan tinggi. Begitu pula, jika kebijakan dividen rendah maka kebijakan utang tersebut akan rendah.

3. Kepemilikan manajerial dan kebijakan dividen secara bersama-sama tidak memiliki pengaruh positif dan signifikan terhadap kebijakan utang. Selain itu, hubungan antara variabel kepemilikan manajerial dan kebijakan dividen terhadap kebijakan utang tergolong rendah. Berdasarkan hasil pengujian data, besaran kebijakan utang non keuangan yang tercatat di Bursa Efek Indonesia dipengaruhi oleh kepemilikan manajerial dan kebijakan dividen sebesar sepuluh koma tiga puluh persen.

\section{Implikasi}

Setelah dilakukan penelitian, diketahui bahwa implikasi dari kepemilikan manajerial dan kebijakan dividen dengan kebijakan utang pada perusahaan non keuangan tahun 2015, sebagai berikut :

1. Pada penelitian ini kepemilikan manajerial dinyatakan tidak berpengaruh terhadap kebijakan utang. Hal ini terjadi karena masih rendahnya persentase yang dimiliki oleh pihak manajerial sehingga manajer tidak berperan sebagai penghindar resiko dalam mengambil keputusan kebijakan utang.

2. Pengaruh kebijakan dividen yang positif dan signifikan terhadap kebijakan utang, menunjukkan bahwa pembagian dividen yang tinggi dapat meningkatkan kebijakan utang. Besarnya laba yang dibagikan untuk pembagian dividen kepada para investor menyebabkan berkurangnya dana untuk perusahaan sehingga perusahaan akan menambah rasio utang.

3. Kepemilikan manajerial dan kebijakan dividen tidak dapat dijadikan pertimbangan untuk menentukan kebijakan utang. Hal ini terjadi karena rendahnya kepemilikan manajerial sehingga manajer tidak membertimbangkan untuk membayarkan dividen yang tinggi sehingga tidak mengurangi free cash flow perusahaan yang dapat di manfaatkan oleh manajer dan tidak mempertimbangkan kebijakan utang.

\section{Saran}

Berdasarkan hasil penelitian, peneliti memiliki beberapa saran yang perlu disampaikan :

1. Perusahaan diharapkan dapat meningkatkan persentase kepemilikan saham manajerial karena hal tersebut dapat menjadi alat pengendali perusahaan untuk para manajer agar dapat berhati-hati dalam menentukan kebijakan utang.

2. Bagi investor, sebelum berinvestasi pada perusahaan sebaiknya memperhatikan kebijakan dividen perusahaan karena hal tersebut mempengaruhi kebijakan utang perusahaan. 
3. Bagi peneliti selanjutnya diharapkan dapat menambahkan jangka waktu penelitian agar memperoleh lebih banyak sampel sehingga dapat menggambarkan kondisi perusahaan non keuangan yang terdaftar di BEI. diharapkan peneliti selanjutnya dapat menggunakan atau menambahkan variabel lain yang mampu menjelaskan variabel kebijakan utang seperti profitabilitas, kepemilikan institusional dan resiko bisnis. Peneliti selanjutnya juga diharapkan dapat menggunakan proksi lain sehingga didapatkan hasil penelitian yang berbeda dengan penelitian ini.

\section{DAFTAR PUSTAKA}

Brimingham dan Houston. Dasar-dasar Manajemen Keuanga, (Jakarta: Salemba Empat, 2011)

Domash, Harry. Fire Your Stock Analyst, (New Jersey: Pearson Education, 2010)

Fahmi, Irham. Pengantar Manajemen Keuangan, (Bandung: Alfabeta, 2014)

Ghozali, Imam. Aplikasi Analisis Multivariate Dengan Program IBM SPSS 20 Edisi 6, (Semarang : Badan Penerbit Universitas Diponegoro, 2011)

Hanafi, M Hanafi. Manajemen Keuangan, (Yogyakarta: BPFE, 2011)

Hidayat, M Syarifudin. pengaruh kepemilikan manajerial, kebijakan dividen, struktur aktiva, pertumbuhan penjualan, dan ukuran perusahaan terhadap kebijakan utang. Jurnal Ilmu Manajemen. Vol 1, No 2.

Hirschey dan Bentzen. Managerial Economic, (Canada: Cengage Learning EMEA, 2016).

Husnan, Suad. , Manajemen keuangan, (Yogyakarta: BPFE, 2000).
Leeds, Peter. Penny Stocks for Dummies, (Wiley).

Mardiyanto, Handono. Inti Sari Manajemen Keuangan, (Jakarta: PT Grasindo, 2009)

Marhamah. Pengaruh kepemilikan manajerial, kepemilikan institusional, kebijakan dividen, pertumbuhan, ukuran perusahaan, dan struktur aktiva terhadap kebijakan hutang perusahaan yang terdaftar di BEI. Jurnal STIE Semarang. Vol 8 No 1 ISSN 2252-826

Masdupi, Erni. Analisis Dampak Struktur Kepemilikan pada Kebijakan Hutang dalam Mengontrol Konflik Keagenan. Jurnal Ekonomi dan Bisnis Indonesia. Vol 20, No 1

Murtiningtyas, Andhika Ivona. Kebijakan deviden, kepemilikan manajerial, kepemilikan institusional, profitabilitas, resiko bisnis terhadap kebijakan hutang. Accounting Analysis Journal. Vol 1, No 2 ISSN 2252-6765

Nursalam. Konsep dan penerapan metedologi penelitian ilmu keperawatan, (Jakarta: Salemba Empat, 2008)

Priyatno, Duwi. Teknik Mudah dan Cepat Melakukan Analisis Data Penelitian Dengan SPSS dan Tanya Jawab Ujian Pendadaran, (Yogyakarta : Gava Media, 2010).

Riyanto, Bambang. Dasar-Dasar Pembelanjaan perusahaan, (Yogyakarta: BPFE).

Rodoni, Ahmad dan Herni Ali. Manajemen Keuangan, (Jakarta: Mitra Wacana Media, 2010).

Rozeff, S Michael. Growth, Beta and Agency Costs as Determinants of Dividend Payout Ratios. the journal of financial research, vol V no 3.

Sawir, Agnes. Kebijakan Pendanaan dan Restrukturisasi perusahaan, (Jakarta: PT Gramedia Pustaka Utama, 2004) 
Diqa Hazna Widya dan Ati Sumiati/ Jurnal Ilmiah Wahana Akuntansi, 12 (2) 2017, 190-208

Sudana, I Made. Manajemen Keuangan Perusahaan, (Jakarta: Erlangga, 2011)

Sugiyono, Metode Penelitian Kuantitatif, Kualitatif dan $R \& D$, (Bandung : Alfabeta, 2011)

Sulaiman, Wahid. Analisis Regresi Menggunakan SPSS Contoh Kasus dan Pemecahannya, (Yogyakarta : Andi Offset, 2004)

Tim Penyusun, Pedoman Penulisan Skripsi Sarjana, (Jakarta : FE UNJ, 2012)

\section{INTERNET}

Cahyadi, Aris. Adira Finance Bagikan Dividen $R p \quad 332,5 \quad$ Miliar.http:// www.beritasatu.com/bank-danpembiayaan/365659-adira-financebagikan-dividen-rp-3325-miliar.html (diakses pada selasa, 7 juni 2016 pukul 15.39 WIB)

Fikry, Muhammad Rausyan. Provident Agro Raih Pinjaman Rp 719,5 Miliar. http:// www.beritasatu.com/emiten/295057provident-agro-raih-pinjaman-rp-7195miliar.html (diakses pada senin, 18 April 2016 pukul 22.12 WIB)

Frateschi, Tiziano. Largest Insiders Trades of the Week. http://www.gurufocus.com/ news/417176/largest-insiders-trades-ofthe-week (diakses pada senin, 13 juni 2016 pukul $02.45 \mathrm{WIB}$ )

MRT. Laba Bersih Angkasa Pura II Turun Tajam 34\%. http://economy.okezone.com/ read/2016/08/15/278/1464260/laba-bersih -angkasa-pura-ii-turun-tajam-34 (diakses pada rabu , 14 september 2016 pukul 18.46 WIB

RZK. PTPP Raih Kontrak Baru Rp 4,98 T

Hingga April. economy.okezone.com/ read/2016/05/02/470/1378425/ptpp-raihkontrak-baru-rp4-98-t-hingga-april (diakses pada kamis, 5 mei 2016 pukul 21.07 WIB)
Utami, Sinar Putri S. Kreditur tak Sepakat, Wirajaya Pailit. nasional.kontan.co.id/news/kreditur-taksepakat-wirajaya-pailit(diakses pada selasa, 7 juni 2016 pukul 15.21 WIB) 